\title{
Language education from a post-native-speakerist perspective: The case of English as an international language ${ }^{1}$ Nobuyuki HINO \\ Osaka University \\ Osaka, Japan
}

\begin{abstract}
Language education has traditionally been based on native-speakerism, which is defined in the present article, by simplifying Holliday's original definition, as a belief in the authority or superiority of native speakers. With the prevalence of native-speakerism, it tends to be taken for granted that non-native speakers should strive to accommodate themselves to native speaker models. However, in today's globalized world, such a conventional attitude is quickly becoming outdated. Above all, a most serious problem with native-speakerism is that it suppresses the freedom of thought and expression as fundamental human rights. Drawing on the case of English as an international language, this study aims to analyze the need for "post-native-speakerism" (a term attributed to Houghton and Hashimoto) in language teaching, or the need for relativizing native speaker norms for language learners. After illustrating major issues of native-speakerism, three theoretical paradigms for post-native-speakerism in global "Englishes" are presented, namely EIL (English as an International Language), WE (World Englishes), and ELF (English as a Lingua Franca), along with a prospect for integrating those different frameworks especially for pedagogical purposes. Then, educational objectives are summarized in terms of language skills, followed by the author's own examples of teaching methodologies and actual classroom practices in higher education. Several key concepts for EIL education emerge from these pedagogical efforts, including authenticity and critical literacy. In view of the urge to embrace diversity in the world today, this paper argues that post-native-speakerism is of vital importance as it allows language users to express their true selves in global communication. While many of the discussions in the present article stem from linguacultural and educational situations in Japan, it is assumed that the insights should often be applicable also to other Expanding Circle, or EFL (English as a Foreign Language), countries such as Russia and China.
\end{abstract}

Keywords: post-native-speakerism, language education, EIL (English as an International Language), WE (World Englishes), ELF (English as a Lingua Franca)

${ }^{1}$ This paper is a revised version of the author's keynote speech with the same title at the QS Subject Focus Summit: Languages and Migration in a Globalized World, RUDN University, Moscow, Russia (online), December 15-17, 2020. It retains, to a certain extent, the colloquial style of the original talk. 


\title{
For citation:
}

Hino, Nobuyuki. 2021. Language education from a post-native-speakerist perspective: The case of English as an itternational language. Russian Journal of Linguistics 25 (2). 528-545. DOI: https://doi.org/10.22363/2687-0088-2021-25-2-528-545

Научная статья

\section{"Post-native-speakerism" как новый подход к языковому образованию: на примере преподавания английского языка как международного 2}

\author{
Нобуюки ХИНО \\ Университет Осаки \\ Осака, Япония
}

\begin{abstract}
Аннотация
Языковое образование традиционно основано на подходе, обозначаемом английским термином "native-speakerism", который, согласно упрощенному определению А. Холлидея, основан на вере в превосходство носителей языка. В рамках этого подхода считается самим собой разумеющимся, что неносители языка должны подстраиваться под коммуникативные модели его носителей. Однако в сегодняшнем глобализованном мире такой подход быстро устаревает. Самая серьезная проблема обусловлена тем, что он подавляет свободу мысли и самовыражения как базовые права человека. Опираясь на рассмотрение английского как языка международного общения, данное исследование анализирует потребность в новом подходе "post-native-speakerism" (Houghton and Hashimoto), основанном на относительности норм, применяемых носителями, для изучающих английский язык как иностранный. Проиллюстрировав основные признаки “native-speakerism”, автор рассматривает три теоретические парадигмы, относящиеся к подходу “post-native-speakerism” в преподавании английского языка: EIL (English as an International Language), WE (World Englishes) и ELF (English as a Lingua Franca), а также возможность их интеграции в педагогическом процессе. Далее суммируются цели, направленные на формирование языковых навыков, и приводятся примеры разработанных автором методик и практических приемов, применяемых на занятиях в вузе. Это дает возможность вывести несколько ключевых понятий для преподавания английского языка как иностранного, таких как аутентичность и критическая грамотность. Учитывая разнообразие сегодняшнего мира, автор утверждает, что подобный подход жизненно необходим, так как он позволяет с помощью языка выразить свое «я» в условиях глобализации. Хотя статья в основном опирается на лингвокультурную ситуацию и систему образования в Японии, предполагается, что сделанные выводы применимы и к другим государствам «расширяющегося круга» (Expanding Circle), а также к преподаванию английского языка как иностранного в таких странах, как Россия и Китай.
\end{abstract}

Ключевые словаs: post-native-speakerism, языковое образование, EIL (English as an International Language), WE (World Englishes), ELF (English as a Lingua Franca)

${ }^{2}$ Статья представляет собой переработанный вариант доклада с тем же названием, представленного на QS саммите "Languages and Migration in a Globalized World", РУДН, Москва, Россия, 15-17 декабря, 2020 г. Она в определенной мере сохраняет разговорный стиль оригинала. 


\section{Для цитирования:}

Hino N. Language education from a post-native-speakerist perspective: The case of English as an iternational language. Russian Journal of Linguistics. 2021. Vol. 25. № 2. P. 528-545. DOI: https://doi.org/10.22363/2687-0088-2021-25-2-528-545

\section{Introduction}

As predicted in the 1970s by Japanese thinkers Kunihiro (1970) and Suzuki (1975) with respect to the learning of English, one of the important tasks for language education in the globalized world is to liberate language learners from native speaker norms so that they may be allowed to express their own values (Honna, 2008). Based on this perception, the present paper discusses the significance of language education from a post-native-speakerist perspective.

The term "native-speakerism" was originally coined and defined in Holliday (2005: 6) as "an established belief that 'native-speaker' teachers represent a 'Western culture' from which spring the ideals both of the English language and of English language teaching methodology." This definition is really insightful in several respects, such as the inclusion of pedagogical issues (cf. Hino, 1992). However, a simpler description of the term may be preferred to maximize the potential of this concept. Also, there seems to be no strong reason to confine the subject of "native-speakerism" only to English. Partly due to these reasons, the present paper simplifies the definition of native-speakerism to refer to "a belief in the authority or superiority of native speakers."

A prevalent Japanese notion known as neitibu chekku (native check) may be cited as a typical example of native-speakerism. Neitibu chekku is an assumption that no English written by a Japanese should be made public before it is checked by a native speaker. Although the Japanese obsession with neitibu chekku is a bit extreme, a similar practice is more or less universal, as used to be the case until quite recently with many international academic journals, which required nonnative English speaking contributors to have their manuscripts proofread by native speakers before submission.

The term "post-native-speakerism" appears as a part of the title of Houghton and Hashimoto (2018). Although no explicit definition of this term seems to be provided by the editors of the book, it is employed in the present paper, along with its handy adjectival form "post-native-speakerist," as a useful expression which broadly refers to ideas or attitudes to overcome native-speakerism.

In the author's personal experience, after I started to learn English in Japan in 1970, I gradually began to wonder - 'So, 'American English' is a means of expressing American values. Then, why not 'Japanese English' for representing Japanese patterns of thought?" (Hino, 1987). That was my initial motive to pursue post-native-speakerism.

Native-speakerism can be an issue in the teaching of any language. For instance, already in the 1980s there was a discussion among leading Japanese scholars about the need to accept varieties of Japanese spoken by non-native 
speakers of the language (Kato et al. 1986). Most recently, along this stream of thought, Aoyama et al. (2020) examines the teaching of Japanese as a lingua franca from a post-native speakerist perspective. However, this paper focuses on the teaching of English as the most salient case in the globalized world. Just for one example, it is nowadays all too common for the majority of participants at international conferences in various fields to be non-native speakers of English, who use English as a lingua franca.

\section{Problems with native-speakerism in teaching English}

In what ways is native-speakerism a problem in teaching English for global communication? This issue may be illustrated at least from three perspectives.

\subsection{Restrictions on the freedom of expression}

Firstly, native-speakerism puts undue restrictions on the freedom of expression as one of the fundamental human rights. For example, Japanese learners of English have generally been taught to say "brother" or "sister" instead of "older brother" or "younger sister," just because it is more common in American English. Actually, just saying "brother" or "sister" does not make much sense for the Japanese, because seniority among siblings is of crucial importance in Japanese culture, or in many Asian cultures. In the teaching of English in Japan, if the student keeps using expressions such as "younger brother" or "older sister," they may be scolded by the teacher for sounding awkward, based on the fact that it is not the way American people usually say. The imposition of native speaker models thus deprives non-native speakers of the freedom of representing their cultural values (cf. Lewis, 2019).

The unreflective adoption of American pedagogical models of text organization in ELT also sometimes imposes serious limitations on the freedom of expression, usually without the awareness of teachers and students. For argumentative writing and speaking, Japanese learners of English are basically instructed to start with a conclusion, followed by the description of a few reasons, before closing with a restatement of the conclusion. This pedagogical practice is based on an educational model learnt from the USA (Watanabe, 2007), although how many Americans actually employ this style in their real life is quite another matter. A major problem, however, is that as a result of this American model, Japanese learners of English take it for granted that they must put forth a one-sided opinion rather than a balanced argument. In fact, in ELT in Japan, students have been strongly discouraged from applying the traditional Japanese argumentative structure "Introduction, development, turn, conclusion" to English, when the conventional Japanese pattern has an advantage of ensuring balance and harmony by reflecting on the other side in the "turn" section. Here, not only are "communicative ethno-styles" (Iliadi and Larina, 2017: 539) disregarded but also the freedom of thought itself is subdued. This is tantamount to a linguistic mind-control. 


\subsection{Relativity in intelligibility}

Secondly, native-speaker English is not necessarily the most intelligible or comprehensible in international communication involving non-native speakers. For example, while native English phonology is characterized by connected speech with stress-timed rhythm, one may have a better chance of being understood, when talking to non-native speakers, by pronouncing English with syllable-timed rhythm coupled with only minimal elision and linking (Hino, 1987, Jenkins, 2000, Deterding \& Kirkpatrick, 2006). It should be kept in mind that interlocutors in English as an international language today are predominantly non-native speakers.

The issue of intelligibility, or comprehensibility ${ }^{3}$, is not restricted to phonology but is related to various other aspects. As to lexical domains, just for one example, Japanese learners of English are often instructed to use the word "junior" in referring to a third-year undergraduate student. However, while this American usage communicates efficiently to Americans, it is not always comprehensible to those who are unfamiliar with American English.

\subsection{Lack of diversity}

And thirdly, native-speakerist teaching of English results in the lack of exposure to diversity, including cultural diversity other than Anglo-American culture. Although Japan appears to be doing comparatively well in this respect as seen in the diversification of the cultural content of junior high school textbooks (Hino, 1988, 2018b), ELT in Japan on the whole is still inclined towards Inner Circle values. For instance, many Japanese students in my undergraduate class found it difficult to understand the below article from a UAE news media outlet:

The United Arab Emirates announced on Wednesday that Eid al-Fitr prayers are to be performed at home instead of mosques this year...

(Al Arabiya English, May 20, 2020) ${ }^{4}$

Learners of English often study Christian rituals like Easter, but they tend to have relatively few opportunities to learn about Islamic culture such as Eid-al-Fitr, a festival at the end of Ramadan.

\section{Theoretical foundation: Post-native-speakerist paradigms for English}

As a theoretical foundation for seeking solutions to the problems of native-speakerism, this section briefly presents three major paradigms for

${ }^{3}$ For a more elaborate treatment of the issue of intelligibility, conceptual distinctions are made among intelligibility, comprehensibility, and interpretability (Smith and Nelson, 1985). With different definitions from those of Smith and Nelson, Murray J. Munro and Tracey M. Derwing also make distinctions among intelligibility, comprehensibility, and accentedness (e.g. Munro and Derwing, 1995; Derwing and Munro, 1997).

${ }^{4}$ URL: https://english.alarabiya.net/en/coronavirus/2020/05/20/Coronavirus-UAE-says-Eidprayers-to-be-performed-at-home-mosques-to-remain-closed.html (accessed May 20, 2020). 
post-native-speakerist approaches to English, namely, WE (World Englishes), ELF (English as a Lingua Franca), and EIL (English as an International Language).

\subsection{WE (World Englishes)}

WE is a paradigm proposed by Braj B. Kachru (1985), while its idea is rooted in Halliday, McIntosh, and Strevens (1964). Simply put, WE refers to varieties of English around the world. It is also known as the three-circle paradigm, dividing the world into the Inner Circle, the Outer Circle, and the Expanding Circle. They respectively refer to Anglophone countries (e.g. UK, USA, and Australia), countries where English is employed as a second language (e.g. India, Singapore, and Philippines), and countries where English is used as a foreign language (e.g. Russia, China, and Japan).

WE research is traced back to the study of domestic use of English in the Outer Circle (Kachru, 1965, 1976), which basically consists of former colonies of the UK and the US. With this background, an emphasis of WE studies has been the analysis of English as an intra-national language, such as when a Singaporean talks to another Singaporean in English. On the other hand, Englishes in the Expanding Circle have often been left behind in WE research. This tendency has been strong also beyond the "Kachruvian" school of WE. For example, a leading theory on the developmental process of varieties of English, the Dynamic Model by Schneider (2003, 2007), is for postcolonial Englishes in the Inner and Outer Circle, and not for Expanding Circle (Schneider, 2014).

While it is true that the number of research publications on Expanding Circle varieties is still relatively limited (Proshina and Nelson, 2020), some notable works have recently been produced on the topic. In addition to the special issue of the Russian Journal of Linguistics devoted to "World Englishes in the Expanding Circle" (Vol. 24, No.3, 2020), they include Proshina and Eddy (2016) which analyzed the functions and features of Russian English.

\subsection{ELF (English as a Lingua Franca)}

ELF is a relatively recent school of thought led by Jennifer Jenkins, Barbara Seidlhofer, and Anna Mauranen (e.g. 2012), with the support of Henry G. Widdowson, a world-renowned authority on applied linguistics.

ELF is usually defined as English for communication between those with different first languages, and is pictured as being fluid, dynamic, and even multilingual or translingual in nature (Jenkins, 2015). The concept of "variation" is preferred by ELF scholars over the notion of "varieties" (Seidlhofer, 2011; Widdownson, 2015), partly because "varieties" are viewed as something static rather than dynamic. That is, ELF is regarded as variation which is situationally and collaboratively constructed.

In fact, according to ELF scholars, ELF is neither a variety nor a collection of varieties (Jenkins, with Cogo \& Dewey, 2011). In other words, concepts such as 
"Indian English" or "Russian English" are de-emphasized in ELF studies. This is a major difference in viewpoints toward ELF and WE, as the latter is seen to comprise varieties of English.

However, it should be also noted that Istvan Kecskes, a highly influential scholar of sociolinguistics, has recently redefined ELF as "a way to put a variety, or several varieties of English to use in interactions between speakers whose L1 is other than English" (Kecskes, 2019: 2). This reinterpretation of ELF is especially significant in that it incorporates the concept of "variety" into ELF. In this connection, it may be also pointed out that ELF studies in its earlier years, which sought to identify common core features across "varieties" of English to ensure mutual intelligibility (Jenkins, 2000), were more useful than later ELF studies focusing on the situational variation of ELF, for pedagogical efforts such as the construction of language models for production (Hino, 2020).

\subsection{EIL (English as an International Language)}

Lastly, EIL is a concept originally proposed by Larry E. Smith from the late 1970 s to the early 1980s. It is also one that I primarily subscribe to, though in a further developed form and often in combination with WE and ELF. While Smith himself largely stopped claiming EIL to be an independent notion after he launched the journal World Englishes as the co-editor with Braj B. Kachru in 1985, I argued in Hino (2001) that the international nature of EIL was significantly different from the intra-national orientation of WE. EIL has in fact been employed as a guiding concept in many high-profile works including McKay (2002), Sharifian (2009), Matsuda (2012a, 2017), and Alsagoff et al. (2012). However, to what extent they draw on Smith's conceptualization of EIL varies among them ${ }^{5}$.

In the present article, EIL refers to English for international communication (Smith, 1976, 1978, 1981). While WE and ELF are often viewed as "rival" schools of thought, EIL is in a way neutral between WE and ELF, since it is possible to regard EIL as an ELF aspect of WE, or the international use of WE. In terms of the aforementioned dichotomy between WE varieties and ELF variation, EIL can be regarded as "variation of varieties" (Hino, 2018b). Defined this way, EIL is both WE and ELF at the same time.

Succinctly summarizing a basic philosophy of EIL, Smith holds that "[1]anguage and culture may be inextricably tied together but no one language is inextricably tied to any one culture" (1981:30). Although Smith does not elaborate on this point in the paper, it is none other than the indigenization, or nativization, of English as a fundamental tenet of WE (Kachru, 1992, 2017), which enables English to represent various values other than its original Anglophone culture. However, EIL differs from the classic WE paradigm in that the concept of indigenization is extended beyond the Outer Circle and as far as Expanding Circle

\footnotetext{
${ }^{5}$ For example, while quoting Smith (1976) as a starting point, McKay (2002) opts to include
} the intra-national use of English in her definition of EIL. 
varieties of English (Hino, 2001), giving hope for Russians and Japanese, for example, to accommodate English to their own needs so as to fully express their voices in English.

One of the major themes for the EIL paradigm is the idea of locally-appropriate pedagogy (Hino, 1992, Holliday, 1994, McKay, 2002, 2003, McKay and Brown, 2015, Matsuda, 2012b), such as a teaching methodology suitable for the Japanese context. Most typically, ELT (English language teaching) in the Expanding Circle like Russia and Japan have different needs from those of the Outer Circle such as India and Singapore.

\subsection{Paradigmatic integration}

A scholar who does not exactly belong to any specific school of thought, but still is highly impactful, is Andy Kirkpatrick. From a non-sectarian position, he incorporates a range of theories into his original research on English for global communication (e.g. Kirkpatrick, 2007, 2010, 2020). Indeed, such a liberal stance should prove to be promising. While each paradigm discussed above has its own unique features, there now seems to be a movement, though not extremely conspicuous yet, toward the integration of those different frameworks. This is a welcome trend which may be further enhanced particularly for the purpose of pedagogical application, considering the importance of being flexible in the postmethod era (Kumaravadivelu, 2001) with an awareness of complexity and dynamism (Larsen-Freeman, 1997).

In order to facilitate an orderly integration of different paradigms of ELT without confusion, I proposed in Hino (2021) an adapted application of four approaches to integration listed by Norcross (2005) in the field of psychotherapy. They are Technical Eclecticism, Theoretical Integration, Common Factors, and Assimilative Integration. For example, Hino (2018b), mentioned in 3.3, may be regarded as Assimilative Integration, as it redefines EIL by assimilating WE and ELF into EIL. Low and Pakir (2018) would also belong to the same category, since the volume rethinks WE with input from ELF and EIL. In a somewhat different orientation, Rose and Galloway (2019), putting forth the concept of GELT (Global Englishes for Language Teaching) which encompasses ELF, WE, and EIL, could be classified as Theoretical Integration. It is hoped that efforts along these lines will be promoted for effective ELT as well as for productive research.

\section{Pedagogical objectives for EIL}

Employing the integrated concept of EIL presented in Hino (2018b) and mentioned above, this section briefly discusses what skills are considered to be the goals of EIL education. All the skills described below concern various aspects including phonological, lexical, grammatical, sociolinguistic, pragmatic, discursive, and non-verbal domains. 


\subsection{Receptive skills for EIL}

In terms of receptive skills, that is, listening and reading skills, a pedagogical objective in teaching EIL is to comprehend both native and non-native varieties of English. Though it depends on each situation, the idea is that teachers should help their students learn to understand not only American and British English but also Vietnamese English, Turkish English, Brazilian English, and so on. As suggested previously in 2.3, EIL education needs to be open to diversity.

A recent and remarkable example is a national standardized examination in Japan known as the Common Test for University Admissions, compulsory for applicants to many Japanese universities. In the first administration of its English exam in January 2021, after a remodeling from its strictly native-speaker-oriented predecessor, the test employed two apparently non-native speakers of English, in addition to native speakers, for the listening comprehension section. Most notably, the distinction between $/ \mathrm{r} /$ and $/ 1 /$ was somewhat ambiguous in the pronunciation of one of the non-native speakers. This is a highly significant change with respect to EIL in that examinees were required to adjust to a non-native pronunciation for the first time when traditionally they had only been tasked to comprehend English spoken with native pronunciation. Considering the enormous washback effect of the standardized university entrance examination, this reform can be a catalyst for further major changes in Japan.

\subsection{Productive skills for EIL}

As for productive skills, or speaking and writing skills for EIL, as evident in 2.1 and 2.2 above, teachers need to help students to learn to communicate their own ideas both to native and non-native speakers. With the dominance of nativespeakerism, Japanese learners of English have been taught to think and behave like Americans, where the criterion for good English has also been intelligibility to native speakers. Users of English must be liberated from native speaker norms in order to be allowed to fully represent their original identities. Models for speaking and writing also need to be redesigned to enhance global intelligibility, comprehensibility, and interpretability (Smith and Nelson, 1985), reaching beyond Inner Circle listeners and readers.

For instance, while Japanese have the cultural habit of expressing appreciation to unspecified others (supposedly not only humans but also nature and gods) before every meal, Japanese learners of English have been discouraged from saying anything before meals, just because Americans do not have such a habit except for the saying of grace in the case of some Christians. From the standpoint of EIL, it is actually a good idea for them to say things like "I'll take this food with thanks" (cf. Lummis, 1982) at international luncheons or dinners, expressing Japanese values as well as giving good impression to other international participants. 


\subsection{Interactive skills for EIL}

In respect of interactive skills, students of EIL need to learn to accommodate to, and to negotiate with, their interlocutors regardless of native or non-native speakers. While in conventional ELT learners are supposed to adhere to interactional norms of the Inner Circle, it is not the case with EIL. For example, Japanese learners of English have often been told to reduce the frequency of their backchannels in accordance with the norms of American English conversations, but frequent backchanneling, or feedbacks, can actually facilitate communication in EIL by lowering the anxiety of one's interlocutor in intercultural interaction.

\section{Pedagogical practice in EIL ${ }^{6}$}

Scholars talk about theories a lot, such as WE, ELF, and EIL. However, the most difficult part has actually been how to put those theories into classroom practice. In fact, after some pioneer projects by the initiator of the EIL paradigm Larry E. Smith and his colleagues (e.g. Smith and Via, 1983; Weiner and Smith, 1983 ) around 1980, post-native-speakerist practices in ELT kept a rather lowprofile, until they finally flourished, driven partly by Sharifian (2009), in the 2010s (e.g. Matsuda, 2012a, Alsagoff et al., 2012, Marlina and Giri, 2014, Bayyurt and Akcan, 2015). As for the present author, I have been pursuing post-nativespeakerist approaches in ELT in Japan since the 1980s, which includes planning and serving as the lecturer for a nationwide radio program dedicated to the teaching of EIL with non-native speaker models from 1989 to 1990 (Hino, 2009, 2018a, $2018 b$ ). This section briefly presents my current pedagogical efforts in EIL at Osaka University ${ }^{7}$.

\subsection{IPTEIL (Integrated Practice in Teaching English as an International Language)}

A method of teaching EIL which has grown out of my undergraduate EFL (English as a Foreign Language) classes is what is now known as IPTEIL (Integrated Practice in Teaching English as an International Language) (Hino, 2012, $2018 \mathrm{~b})$. In this method, I engage my students in the authentic task of reading the latest, real-time news from English news media across the world. This task is authentic in the sense that the information the students obtain from the English news articles is not available yet in their first language, Japanese, at that point. In fact, at

\footnotetext{
${ }^{6}$ In compliance with the theoretical and linguistic focus of the Russian Journal of Linguistics, the present article keeps the practical descriptions of classroom practice relatively concise. Readers are referred to Hino $(2012,2018 \mathrm{~b})$ as well as Hino and Oda (2015) for more detailed discussions of IPTEIL (5.1), and to Hino $(2018 b, 2019)$ along with Hino and Oda (2020) in regard to those of CELFIL (5.2).

${ }^{7}$ Although beyond the realm of this paper, "virtual exchange" (O’Dowd, 2017), connecting university classrooms globally, is also a useful approach to the teaching of EIL. CCDL (Cross-Cultural Distance Learning), practiced at Waseda University, Japan, is one of the pioneers in this category (Ueda et al., 2005).
} 
the beginning of January 2020, my class discussed one of the very first reports on the coronavirus outbreak, at least several hours before Japanese newspapers and television news programs began to talk about it.

One activity in the IPTEIL class is comparing and contrasting different perspectives on a same topic by reading various news media. This activity combines the teaching of EIL with critical literacy and global education in the form of CBI (Content-Based Instruction). I had long practiced IPTEIL in face-to-face classes, and amid the COVID situation I have found it to be also usable in online Zoom classes.

Below is a recent example from my recent IPTEIL class. On the November $12^{\text {th }}$ 2020 session, we compared articles from American CNN, national Ethiopian news agency ENA, and national Sudanese news agency SUNA, with regard to the conflict between the central Ethiopian government and the governing body of the local Tigray region. We started with reading the $\mathrm{CNN}$ article:

“...Abiy is facing international diplomatic pressure from the United States, the United Kingdom and the UN to de-escalate tensions, but so far has continued the military operation" (CNN, November 12, 2020).

The basic tone of this CNN article is to criticize the Prime Minister Abiy of Ethiopia for his military actions, particularly in light of the fact that he received Nobel Peace Prize the previous year. Next, we examined how the state media of Ethiopia, ENA, reported on the same issue from the perspective of Prime Minister Abiy's central Ethiopian government:

"Deputy Prime Minister and Foreign Minister Demeke... pointed out that the government intends to neutralize the destructive force of the TPLF gang, free the people..." (ENA, November 12, 2020) .

The ENA article calls the local Tigray force a gang who suppresses the freedom of people. This is a very different viewpoint from that of American CNN. Then, we also read an article from SUNA, a state media of Ethiopia's neighbor, Sudan:

"More than 5,000 of the Ethiopian refugees including a big number of women and children who fled the war in the Ethiopian region of Tigri arrived in Kassala and Gadarif..." (SUNA, November 12, 2020) ${ }^{10}$.

The article offers another perspective by showing that the primary concern for Sudan is the influx of refugees from Ethiopia.

Thus, in the IPTEIL class, students learn how the same event is viewed differently from various perspectives. Indeed, in order to function as a user of EIL, critical literacy is of utmost importance. Without critical thinking and media literacy, we will be easily lost in the world of EIL, which is an intersection of a diversity of values.

${ }^{8}$ URL: https://edition.cnn.com/2020/11/12/africa/ethiopia-tigray-killings-intl/index.html (accessed November 12, 2020).

${ }^{9}$ URL: https://www.ena.et/en/?p=18499 (accessed November 12, 2020).

${ }^{10}$ URL: https://suna-sd.net/en/single?id=697584 (accessed November 12, 2020). 


\subsection{CELFIL (Content and English as a Lingua Franca Integrated Learning)}

Another approach to the teaching of EIL is what I call CELFIL (Content and English as a Lingua Franca Integrated Learning) (Hino, 2015, 2017a) ${ }^{11}$. I have been working to develop this methodology as CLIL for EIL in EMI (English-Medium Instruction). The term ELF has been chosen as a part of the name of this approach for the purpose of emphasizing its ELF aspects, or inter-linguacultural interaction.

The increase of EMI courses is a world-wide trend today especially in higher education, and one of the advantages of EMI classes is oftentimes the diversity of student demographics, brought about by the participation of international students along with local students. For example, my Master-level graduate EMI class on language education in 2018-2019 had students from Russia, China, Malaysia, and Japan. This is an authentic EIL environment, where students can experience EIL interaction in person.

A feature activity of CELFIL, which has also emerged from my classroom practice, is a unique type of small group discussion that I have named OSGD (Observed Small Group Discussion) (Hino, 2017b, 2018b) ${ }^{12}$. In usual small group discussion, the teacher organizes several small groups, and all those groups have discussions concurrently. However, in OSGD, I organize just one small group, and have all other students observe the discussion.

I have tried OSGD via Zoom under the coronavirus situation after practicing it for several years in face-to-face classes. OSGD works basically as well with Zoom, although the occasional difficulty of guessing exactly who the participants are talking to is slightly a problem.

After the observed small-group discussion, the class has a whole-class discussion, which analyzes what the students have observed as observers or experienced as discussants. Topics of the whole-class discussion cover both the content of the small-group discussion and the use of communication strategies. In regard to communication strategies, students in my classes have pointed out the use of clarification, confirmation, code-switching (or more broadly, translanguaging), backchannels, and non-verbal cues.

The following dialog is an example from OSGD, in which the discussants were two students from China and the other two from Japan:

Chinese A: Sorry... More specifically about it?

Chinese B: Ah...?

Chinese A: Gutaiteki ni douiukotoka?

Chinese B: Ah...

Chinese A: Can you speak your question?

(Hino \& Oda, 2020: 306)

${ }^{11}$ Smit (2013) proposes a concept called ICELF (Integrating Content and English as a Lingua Franca), where the learning of ELF is incidental to EMI. For CELFIL, on the other hand, EMI is actively redesigned to include the learning of ELF as an explicit pedagogical goal.

12 OSGD is intended to be pronounced as "Osgood," partly as a tribute to American psychologist Charles E. Osgood, who laid the foundation for the psychological analysis of language learning. 
The third line in this exchange, "Gutaiteki ni douiukotoka?" is Japanese, which means "Could you be more specific?" What happened here is that when a clarification was needed in the conversation, Chinese A student switched to Japanese rather than to Chinese in spite of the fact that he was talking to a fellow Chinese student.

In the whole-class discussion, we asked Chinese A why he had switched to Japanese instead of Chinese. He answered that switching to Chinese would have been discourteous to those who did not understand Chinese, and explained that he rather switched to Japanese so that no one would be excluded from the discussion, as all the participants in this class understood Japanese. This was a useful instance for students to learn about translanguaging in an authentic EIL situation.

In OSGD, students who served as observers will serve as discussants in the next session. There, they can apply the communication strategies that they learnt as observers to their own discussions. In this way, students learn collaborative meaning-making in EIL interaction through observation, reflection, and practice.

\section{Conclusion}

This paper has discussed a post-native speakerist language education, chiefly based on an example of teaching EIL in Japan. Native-speakerism, a belief in the authority or supremacy of native speakers, is problematic for language education in that it often restricts the freedom of expression, reduces international intelligibility, and works against diversity. It has been shown in this article that the objectives of post-native-speakerist teaching of EIL should include the acceptance of linguacultural varieties of English as well as the representation of the student's own values, along with the need to deal with the fluid nature of intercultural communication. As classroom pedagogy is striving to to achieve these goals, two methods of teaching with authentic EIL tasks, namely IPTEIL and CELFIL, have been presented, where the former exposes learners to the linguacultural diversity of WE and the latter engages students in the interactional dynamism of ELF.

Toward the construction of a world which is open to diversity, language education from post-native-speakerist perspectives is urgently needed today. Liberation from native speaker norms, as evident with the case of EIL, will allow individuals to express their identities while promoting intercultural communication through accommodation and negotiation.

(C) Nobuyuki Hino, 2021
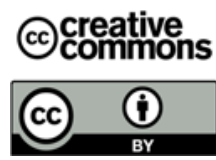

This work is licensed under a Creative Commons Attribution 4.0 International License https://creativecommons.org/licenses/by/4.0/ 


\section{Acknowledgements}

This research is partly supported by JSPS KAKENHI, Grant Number JP18K00738. I am grateful to Professor Tatiana V. Larina as well as to two anonymous reviewers for their valuable comments on the article.

\section{REFERENCES}

Alsagoff, Lubna, Sandra L. McKay, Guangwei Hu \& Willy A. Renandya (eds.). 2012. Principles and Practices for Teaching English as an International Language. New York: Routledge.

Aoyama, Reijiro, Tomoko Akashi, David C. S. Li \& Maggie O. U. Leung (eds.). 2020. Ringafuranka to Shiteno Nihongo: Tagengo-tabunka-kyosei no tameni Nihongokyoiku o Saikosuru [Japanese as a Lingua Franca: Rethinking Japanese Language Education for Multilingual and Multicultural Contexts]. Tokyo: Akashi shoten.

Bayyurt, Yasemin \& Sumru Akcan (eds.) 2015. Current Perspectives on Pedagogy for English as a Lingua Franca. Berlin: De Gruyter Mouton.

Derwing, Tracey M. \& Murray J. Munro. 1997. Accent, intelligibility, and comprehensibility: Evidence from four L1s. Studies in Second Language Acquisition 19 (1). 1-16.

Deterding, David \& Andy Kirkpatrick. 2006. Emerging South-East Asian Englishes and intelligibility. World Englishes 25 (3-4). 391-409.

Halliday, Michael, Angus K. McIntosh \& Peter Strevens. 1964. The Linguistic Sciences and Language Teaching. Bloomington: Indiana University Press.

Hino, Nobuyuki. 1987. TOEFL de 650-ten: Watashi no Eigoshugyo [650 on the TOEFL: My Experiences in Learning English]. Tokyo: Nan'undo.

Hino, Nobuyuki. 1988. Nationalism and English as an international language: The history of English textbooks in Japan. World Englishes 7 (3). 309-314.

Hino, Nobuyuki. 1992. The yakudoku tradition of foreign language literacy in Japan. In Dubin, F. \& N. A. Kuhlman (eds.), Cross-Cultural Literacy: Global Perspectives on Reading and Writing, 99-111. Englewood Cliffs, NJ: Regents/Prentice Hall.

Hino, Nobuyuki. 2001. Organizing EIL studies: Toward a paradigm. Asian Englishes 4 (1). 34-65.

Hino, Nobuyuki. 2009. The teaching of English as an international language in Japan: An answer to the dilemma of indigenous values and global needs in the Expanding Circle. AILA Review 22. 103-119.

Hino, Nobuyuki. 2012. Participating in the community of EIL users through real-time news: Integrated practice in teaching English as an international language (IPTEIL). In A. Matsuda (eds.) Principles and Practices of Teaching English as an International Language, 183-200. Bristol: Multilingual Matters.

Hino, Nobuyuki. 2015. Toward the development of CELFIL (Content and ELF integrated learning) for EMI classes in higher education in Japan. Waseda Working Papers in ELF 4. 187-198.

Hino, Nobuyuki. 2017a. Training graduate students in Japan to be EIL teachers. In A. Matsuda (eds.), Preparing Teachers to Teach English as an International Language, 87-99. Bristol: Multilingual Matters.

Hino, Nobuyuki. 2017b. Tabunkakyosei no tame no kokusaieigo-kyoiku [EIL education for multicultural symbiosis]. In Y. Imao, Y. Okada, I. Koguchi \& N. Hayase (eds.), Eigokyoiku tettei rifuresshu: Gurobaruka to 21-seikigata no kyoiku [Completely refreshing the teaching of English: Globalization and education for the 21st century], 2-13. Tokyo: Kaitakusha. 
Hino, Nobuyuki. 2018a. Pedagogy for the post-native-speakerist teacher of English. In S. A. Houghton \& K. Hashimoto (eds.), Towards Post-Native-Speakerism: Dynamics and shifts, 217-233. Singapore: Springer.

Hino, Nobuyuki. 2018b. EIL Education for the Expanding Circle: A Japanese Model. London: Routledge.

Hino, Nobuyuki. 2019. Designing CELFIL (content and ELF integrated learning) for EMI classes in higher education in Japan. In K. Murata (eds.), English-medium instruction from an English as a lingua franca perspective: Exploring the higher education context, 219-238. London: Routledge.

Hino, Nobuyuki. 2020. English as a lingua franca from an applied linguistics perspective: In the context of Japan. Russian Journal of Linguistics 24 (3). 633-648. DOI: https://doi.org/10.22363/2687-0088-2020-24-3-633-648

Hino, Nobuyuki \& Setsuko Oda. 2015. Integrated Practice in Teaching English as an International Language (IPTEIL): A classroom ELF pedagogy in Japan. In Y. Bayyurt \& S. Akcan (eds.), Current Perspectives on Pedagogy for English as a Lingua Franca, 3550. Berlin: De Gruyter Mouton.

Hino, Nobuyuki \& Setsuko Oda. 2020. CLIL pedagogy for EIL in higher education. In R. A. Giri, A. Sharma, \& J. D’Angelo (eds.), Functional Variations in English: Theoretical Considerations and Practical Challenges, 295-309. Cham, Switzerland: Springer.

Holliday, Adrian. 1994. Appropriate Methodology and Social Context. Cambridge: Cambridge University Press.

Holliday, Adrian. 2005. The Struggle to Teach English as an International Language. Oxford: Oxford University Press.

Honna, Nobuyuki. 2008. English as a Multicultural Language in Asian Contexts: Issues and Ideas. Tokyo: Kurosio Publishers.

Houghton, Stephanie A. \& Kayoko Hashimoto (eds.). 2018. Towards Post-Native-Speakerism: Dynamics and Shifts. Singapore: Springer.

Iliadi, Paraskevi-Lukeriya \& Tatiana V. Larina. 2017. Refusal strategies in English and Russian. RUDN Journal of Language Studies, Semiotics and Semantics 8 (3). 531-542. DOI: https://doi.org/10.22363/2313-2299-2017-8-3-531-542

Jenkins, Jennifer. 2000. The Phonology of English as an International Language. Oxford: Oxford University Press.

Jenkins, Jenkins, Alessia Cogo \& Martin Dewey. 2011. Review of developments in research into English as a lingua franca. Language Teaching 44 (3). 281-315.

Jenkins, Jennifer. 2015. Repositioning English and multilingualism in English as a lingua franca. Englishes in Practice 2 (3). 49-85.

Kachru, Braj B. 1965. The Indianness in Indian English. Word 21 (3). 391-410.

Kachru, Braj B. 1976. Models of English for the Third World: White man's linguistic burden or language pragmatics? TESOL Quarterly 10 (2). 221-239.

Kachru, Braj B. 1985. Standards, codification and sociolinguistic realism: The English language in the Outer Circle. In R. Quirk \& H. G. Widdowson (eds.), English in the World: Teaching and Learning the Language and Literatures, 11-30. Cambridge: Cambridge University Press.

Kachru, Braj B. (eds.). 1992. The Other Tongue. Oxford: Pergamon Press.

Kachru, Braj B. 2017. World Englishes and Culture Wars. Cambridge: Cambridge University Press.

Kato, Hidetoshi, Tadao Umesao, Shuichi Kato, Shuntaro Ito, Osamu Mizutani \& Minoru Kusuda. 1986. Zadankai "Kokusaikasuru nihongo no zahyojiku" (Roundtable talk "The coordinate axis for internationalizing Japanese"). Kokusai-koryu 41. 2-29. 
Kecskes, Istvan. 2019. English as a Lingua Franca: The Pragmatic Perspective. Cambridge: Cambridge University Press.

Kirkpatrick, A. 2007. World Englishes: Implications for International Communication and English Language Teaching. Cambridge: Cambridge University Press.

Kirkpatrick, A. 2010. English as a Lingua Franca in ASEAN: A Multilingual Model. Hong Kong: Hong Kong University Press.

Kirkpatrick, Andy. 2020. Englishes in the Expanding Circle: Focus on Asia. Russian Journal of Linguistics 24 (3). 551-568. DOI: https://doi.org/10.22363/2687-0088-202024-3-551-568

Kumaravadivelu, B. 2001. Toward a postmethod pedagogy. TESOL Quarterly 35 (4). 537-560. Kunihiro, Masao. 1970. Eigo no Hanashikata [English Works for You]. Tokyo: Simul Press.

Larsen-Freeman, Diane. 1997. Chaos/complexity science and second language acquisition. Applied Linguistics 18 (2). 141-165.

Lewis, Richard D. 2019. The cultural imperative: Global trends in the 21 st century. Training, Language and Culture 3 (3). 8-20. DOI: https://doi.org/10.29366/2019tlc.3.3.1

Low, Ee-Ling \& Anne Pakir (eds.). 2018. World Englishes: Rethinking Paradigms. London: Routledge.

Lummis, Douglas. 1982. Nihonjin no ningenkankei o eigo de hyogen dekiruka. Honyaku no sekai 7 (5). 26-27.

Marlina, Robin \& Ram A. Giri (eds.). 2014. The Pedagogy of English as an International Language: Perspectives from Scholars, Teachers, and Students. Cham, Switzerland: Springer.

Matsuda, Aya. (eds.). 2012a. Principles and Practices of Teaching English as an International Language. Bristol: Multilingual Matters.

Matsuda, Aya. 2012b. Teaching materials in EIL. In L. Alsagoff, S. L. McKay, G. Hu \& W. A. Renandya (eds.), Principles and Practices for Teaching English as an International Language, 168-185. New York: Routledge.

Matsuda, Aya. (eds.). 2017. Preparing Teachers to Teach English as an International Language. Bristol: Multilingual Matters.

Mauranen, Anna. 2012. Exploring ELF: Academic English Shaped by Non-native Speakers. Cambridge: Cambridge University Press.

McKay, Sandra L. 2002. Teaching English as an International Language. Oxford: Oxford University Press.

McKay, Sandra. 2003. Teaching English as an international language: The Chilean context. ELT Journal 57 (2). 139-148.

McKay, Sandra L. \& James D. Brown. 2015. Teaching and Assessing EIL in Local Contexts around the World. New York: Routledge.

Munro, Murray J. \& Tracey M. Derwing. 1995. Foreign accent, comprehensibility, and intelligibility in the speech of second language learners. Language Learning 45 (1). 73-97.

Norcross, John C. 2005. A primer on psychotherapy integration. In J.C. Norcross \& M.R. Goldfried (eds.), Handbook of Psychotherapy Integration, 3-23. Oxford: Oxford University Press.

O'Dowd, Robert. 2017. Virtual Exchange and internationalising the classroom. Training, Language and Culture 1 (4). 8-24. DOI: https://doi.org/10.29366/2017tlc.1.4.1

Proshina, Zoya G. \& Anna A. Eddy (eds.). 2016. Russian English: History, Functions, and Features. Cambridge: Cambridge University Press.

Proshina, Zoya G. \& Cecil L. Nelson. 2020. Varieties of English and Kachru's Expanding Circle. Russian Journal of Linguistics 24 (3). 523-550. DOI: https://doi.org/10.22363/ 2687-0088-2020-24-3-523-550 
Rose, Heath \& Nicola Galloway. 2019. Global Englishes for Language Teaching. Cambridge: Cambridge University Press.

Schneider, Edgar W. 2003. The dynamics of new Englishes: From identity construction to dialect birth. Language 79 (2). 233-281.

Schneider, Edgar W. 2007. Postcolonial English: Varieties around the World. Cambridge: Cambridge University Press.

Schneider, Edgar W. 2014. New reflections on the evolutionary dynamics of world Englishes. World Englishes 33 (1). 9-32.

Seidlhofer, Barbara. 2011. Understanding English as a Lingua Franca. Oxford: Oxford University Press.

Sharifian, Farzad (eds.). 2009. English as an International Language: Perspectives and Pedagogical Issues. Bristol: Multilingual Matters.

Smit, Ute. 2013. Learning affordances in integrating content and English as a lingua franca ("ICELF"): on an implicit approach to English medium teaching. Journal of Academic Writing 3 (1). 15-29.

Smith, Larry E. 1976. English as an international auxiliary language. RELC Journal 7 (2). 38-53. Also in Smith, L. E. (ed.) 1983. Readings in English as an International Language, 1-5. Oxford: Pergamon Press.

Smith, Larry E. 1978. Some distinctive features of EIIL vs. ESOL in English language education. The Culture Learning Institute Report, June, 5-7 \& 10-11. Also in Smith, L. E. (ed.) 1983. Readings in English as an International Language, 13-20. Oxford: Pergamon Press.

Smith, Larry E. 1981. English as an international language: No room for linguistic chauvinism. Nagoya Gakuin Daigaku Gaikokugo Kyoiku Kiyo 3. 27-32. Also in Smith. L. E. (ed.) 1983. Readings in English as an international language, 7-11. Oxford: Pergamon Press.

Smith, Larry E. \& Richard A. Via. 1983. English as an international language via drama techniques. In L. E. Smith (eds.), Readings in English as an international language, 111-116. Oxford: Pergamon Press.

Smith, Larry E. \& Cecil L. Nelson. 1985. International intelligibility of English: Directions and resources. World Englishes 4 (3). 333-342.

Suzuki, Takao. 1975. Tozasareta Gengo, Nihongo no Sekai [A Closed Language: The World of Japanese]. Tokyo: Shinchosha.

Ueda, Norifumi, Owada, Kazuharu, Oya, Masanori \& Tsutsui, Eiichiro. 2005. Shakai e tsunageru daigaku-eigokyoiku [University English language education in social contexts]. In Nakano, M. (ed.) Eigokyoiku gurobaru dezain [Global design for Engilsh language teaching], 135-173. Tokyo: Gakubunsha.

Watanabe, Masako. 2007. Nichi-bei-futsu no kokugokyoiku o yomitoku: "Yomikaki" no rekishishakaigakuteki kosatsu [A comparison of language arts education in the three countries, Japan, the United States and France: Sociohistorical analyses of reading and writing]. Nihon Kenkyu 35, 573-619.

Weiner, Eva S. \& Larry E. Smith. 1983. English as an International Language: A Writing Approach. Oxford: Pergamon Press.

Widdowson, Henry. 2015. ELF and the pragmatics of language variation. Journal of English as a Lingua Franca 4 (2). 359-372.

\section{Internet resources}

Hino, Nobuyuki. 2021. Integrating EIL, WE, and ELF paradigms in teaching English for global communication. Invited speech at the 55th RELC International Conference, Singapore, March 15-17. 


\section{Article history:}

Received: 12 December 2020

Accepted: 22 March 2021

\section{История статьи:}

Дата поступления в редакцию: 12 декабря 2020

Дата принятия к печати: 22 марта 2021

\section{Bionote:}

Nobuyuki HINO, Ph.D. (Language and Culture, Osaka University) is Professor, Graduate School of Language and Culture, Osaka University, Japan. He serves on editorial/advisory boards for Routledge, Wiley, and Springer. Along with numerous journal articles and book chapters on the teaching of EIL (English as an International Language), he is the author of EIL education for the Expanding Circle: A Japanese model (Routledge, 2018). His research interests include applied linguistics, language pedagogy, and diversity education.

\section{Contact information:}

Osaka University

Graduate School of Language and Culture, 1-8 Machikaneyama-cho, Toyonaka, Osaka 560-0043 Japan

e-mail: hino@lang.osaka-u.ac.jp

ORCID: 0000-0001-8761-6278

\section{Сведения об авторе:}

Нобуюки ХИНО, Ph.D., профессор Высшей школы языка и культуры Университета Осаки, Япония. Является членом редакционных советов издательств Routledge, Wiley, Springer, a также автором многочисленных статей, глав коллективных монографий и книги "EIL Education for the Expanding Circle: A Japanese Model" («Преподавание английского языка как международного для расширяющегося круга: японская модель), Routledge, 2018. Его исследовательские интересы включают прикладную лингвистику и языковое образование.

\section{Контактная информация:}

Osaka University

Graduate School of Language and Culture, 1-8 Machikaneyama-cho, Toyonaka, Osaka 560-0043 Japan

e-mail: hino@lang.osaka-u.ac.jp

ORCID: 0000-0001-8761-6278 